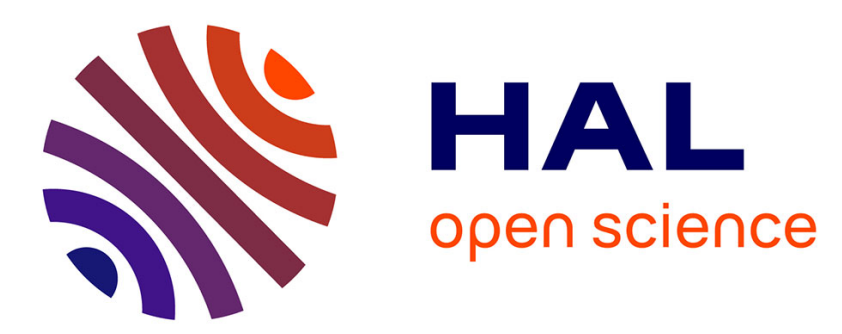

\title{
Analysis of Lactosylated $\beta$-Lactoglobulin by Capillary Electrophoresis
}

\author{
J. Otte, K.S. Larsen, Said Bouhallab
}

\section{To cite this version:}

J. Otte, K.S. Larsen, Said Bouhallab. Analysis of Lactosylated $\beta$-Lactoglobulin by Capillary Electrophoresis. International Dairy Journal, 1998, 8 (10-11), pp.857-862. 10.1016/S0958-6946(98)00128-

9. hal-01559702

\author{
HAL Id: hal-01559702 \\ https://hal.science/hal-01559702
}

Submitted on 10 Jul 2017

HAL is a multi-disciplinary open access archive for the deposit and dissemination of scientific research documents, whether they are published or not. The documents may come from teaching and research institutions in France or abroad, or from public or private research centers.
L'archive ouverte pluridisciplinaire HAL, est destinée au dépôt et à la diffusion de documents scientifiques de niveau recherche, publiés ou non, émanant des établissements d'enseignement et de recherche français ou étrangers, des laboratoires publics ou privés.

\section{다(1)(2)}

Distributed under a Creative Commons Attribution - ShareAlikel 4.0 International 


\title{
Analysis of Lactosylated $\beta$-Lactoglobulin by Capillary Electrophoresis
}

\author{
J. Otte ${ }^{a *}$, K. S. Larsen ${ }^{a}$ and S. Bouhallab ${ }^{b}$ \\ ${ }^{a}$ Department of Dairy and Food Science, The Royal Veterinary and Agricultural University, Rolighedsvej 30, \\ DK-1958 Frederiksberg C, Denmark \\ ${ }^{b}$ Institut National de la Recherche Agronomique, Laboratoire de Recherches de Technologie Laitière, \\ 65 rue de Saint Brieuc, 35042 Rennes, France
}

(Received 11 November 1998; accepted 13 November 1998)

\begin{abstract}
Variously lactosylated species of $\beta$-lactoglobulin $\mathrm{AB}$ were analysed by capillary electrophoresis at low $\mathrm{pH}$ and high $\mathrm{pH}$ with and without buffer additives. By simple capillary zone electrophoresis at either low or high $\mathrm{pH}$ the lactosylated forms had longer migration times than the native $\beta$-lactoglobulin, most likely due to their larger molecular size and lower pI. By micellar electrokinetic chromatography using SDS as detergent the lactosylated forms of $\beta$-lactoglobulin had shorter migration times than the native species, due to less interaction with the micelles. The methods used were also able to distinguish between more or less lactosylated forms of $\beta$-lactoglobulin. By all methods used, partial separation of at least five forms of $\beta$-lactoglobulin were obtained. However, baseline separation of $\beta$-lactoglobulin with varying number of lactose units attached was not obtained, probably due to the presence of both variants of $\beta$-lactoglobulin with various numbers of lactosyl groups at different sites. (C) 1999 Elsevier Science Ltd. All rights reserved
\end{abstract}

Keywords: $\beta$-lactoglobulin; lactosylated; capillary electrophoresis

\section{INTRODUCTION}

With the use of mass spectrometry (MS) for protein analysis it has become evident that lactosylation of $\beta$ lactoglobulin $(\beta-\mathrm{Lg})$ occurs during processing of milk and whey (Burr et al., 1996; Morgan et al., 1997; Léonil et al., 1997). Since the non-enzymatic lactosylation occurs at a temperature not significantly higher than the temperature of the cow practically all preparations of whey protein contain a certain fraction of lactosylated $\beta-\mathrm{Lg}$ (Morgan et al., 1997, 1998), which has not been evidently revealed by the analytical methods previously used. Lactosylation might affect the biological as well as the functional properties of the protein.

Lactosylation occurs by a condensation between lactose and protein-bound amino groups through the Maillard reaction. Morgan and co-workers have shown that the $\mathrm{N}$-terminal amino group and all lysine residues in $\beta$ - $\mathrm{Lg}$, with the exception of Lys101, may be lactosylated, depending on the duration and severity of heat treatment as well as on the water activity (Morgan et al., 1998).

The purpose of the present study is to use capillary electrophoresis, a high-resolution analytical method, for separation of variously lactosylated forms of $\beta$ - Lg. Capillary electrophoresis (CE) has previously been used for separation of micro-heterogeneous proteins, including variously glycosylated forms (Taverna et al., 1992;

*Corresponding author. E-mail: jo@kvl.dk.
Vincentelli and Bihoreau, 1993; Otte et al., 1995; Oda and Landers, 1996). No reports, however, have been found on the CE separation of lactosylated proteins. In simple capillary zone electrophoresis (CZE) the analytes are separated in an electric field according to their chargeto-mass ratio. The electrophoretic mobility, $\mu_{\mathrm{e}}$, is a function of the electric force, $F_{\mathrm{e}}=q E$, and of the frictional force, $F_{\mathrm{f}}=6 \pi \eta r v$, where $q$ is the net charge, $E$ is the electrical field strength, $\eta$ is the viscosity of the buffer, $r$ is the radius and $v$ the migration velocity. At constant migration velocity these forces are balanced, which means that the electrophoretic mobility is a function of the charge/radius ratio: $\mu_{\mathrm{e}}=q / 6 \pi \eta r$. The attachment of lactosyl groups with the formation of a stable ketoamine may lead to slight changes in the charge of the protein (Morgan et al., 1998; Nacka et al., 1998). Furthermore, the size and conformation of the protein may be slightly changed, which may increase the frictional force and affect the migration of the condensation product.

By introducing a micelle-forming detergent into the electrophoresis buffer, a chromatographic dimension is superimposed on the electrophoretic separation. In this mode, named micellar electrokinetic chromatography (MECC), the analytes are separated according to their partition coefficient between the pseudostationary phase formed by the micelles and the mobile aqueous phase carried by the electro-osmotic flow. This separation principle is especially suited for analysis of small uncharged molecules, but has also been used for separation of proteins (Arentoft et al., 1993; Strege and Lagu 1993; Kats et al., 1997). 


\section{MATERIALS AND METHODS}

\section{Materials}

$\beta$ - $\operatorname{Lg} \mathrm{AB}$ was purified as described by Léonil et al. (1997). Pure $\beta$ - $\mathrm{Lg} \mathrm{A}$ and B were isolated as described by Kristiansen et al. (1998). Other chemicals used were analytical grade chemicals purchased from Merck (E. Merck, Darmstadt, Germany). High quality water (MilliQ Plus, Millipore Corporation) was used for preparation of all samples and buffers.

\section{Lactosylation}

The $\beta$ - $\operatorname{Lg} \mathrm{AB}$ sample was lactosylated in solution as described by Morgan et al. (1997), and under reduced humidity (dry-way) as described by Morgan et al. (1998). The following five samples were obtained:

(1) CT1: native, untreated;

(2) CT2: control, heated as BL3 but without lactose $\left(50^{\circ} \mathrm{C}, 65 \%\right.$ relative humidity $\left.(\mathrm{RH}), 40 \mathrm{~h}\right)$;

(3) BL1: Lactosylated in solution $\left(65^{\circ} \mathrm{C}, 15 \mathrm{~h}\right)$, resulting in an average of 0.7 lactose $/ \beta$ - $\mathrm{Lg}$;

(4) BL2: dry-way lactosylated $\left(65 \% \mathrm{RH}, 50^{\circ} \mathrm{C}, 6 \mathrm{~h}\right)$, resulting in an average of 2.4 lactose $/ \beta$ - Lg;

(5) BL3: dry-way lactosylated $\left(65 \% \mathrm{RH}, 50^{\circ} \mathrm{C}, 40 \mathrm{~h}\right)$, resulting in $6-8$ lactose $/ \beta$-Lg.

\section{Capillary electrophoresis}

Samples were dissolved in water at $4 \mathrm{mg} / \mathrm{mL}^{-1}$ and analysed by CZE using a range of buffers as well as by MECC using SDS as detergent (Table 1). Capillary electrophoresis was performed on a HP3DCE instrument (G1602A, Hewlett-Packard A/S, Waldbronn, Germany), mounted with an untreated $50 \mu \mathrm{m}$ i.d. fused-silica capillary of $64.5 \mathrm{~cm}$ total length. Samples were injected hydrodynamically $(4 \mathrm{~s}$ at $50 \mathrm{mbar}$ ) at the anode. Some analyses (CZE at pH 2.5) were performed using a Waters Quanta 4000 instrument (Waters, Division of Millipore, Milford, MA 01757, US) and a capillary of $60 \mathrm{~cm}$. Injection in this system was performed hydrodynamically for $20 \mathrm{~s}$. In both cases the voltage was adjusted to give a current of $40-50 \mu \mathrm{A}$.

\section{Size-exclusion HPLC (SE-HPLC)}

SE-HPLC was performed as described by Færgemand et al. (1998) using a TSK Gel G-2000 column and a phosphate buffer containing $0.15 \mathrm{M} \mathrm{NaCl}$. Before analysis, samples were diluted to a protein content of $1.0 \mathrm{mg} \mathrm{mL}^{-1}$.

\section{RESULTS AND DISCUSSION}

\section{Capillary zone electrophoresis (CZE)}

\section{Low $p H$}

Capillary electrophoresis of the control samples at low $\mathrm{pH}$ showed one major peak (with slight tailing), which is attributed to native $\beta$ - $\operatorname{Lg}$ (Fig. 1). The partly splitting of this peak in some samples (CT1 and BL2) could be due to partly resolving of the genetic variants, although they should carry an equal positive charge at $\mathrm{pH} 2.5$. Analysis of the mildly lactosylated sample (BL1, Fig. 1) showed that in addition to the peak for native $\beta$ - $\mathrm{Lg}$ a range of closely migrating peaks with longer retention times were present. In consideration of the relative increase in the areas of these peaks with increasing lactosylation and of the very long migration time of the most lactosylated $\beta$-Lg sample (BL3) the peaks with migration times longer than the native $\beta$-Lg must represent lactosylated forms of $\beta$-Lg. From Fig. 1 it seems, thus, that by using a simple phosphate buffer of low $\mathrm{pH}$ it is possible by $\mathrm{CE}$ to differentiate between native and lactosylated $\beta$ - $\mathrm{Lg}$ as well as between $\beta$ - $\mathrm{Lg}$ molecules with varying degrees of lactosylation.

Incubation of the sample with urea and dithiothreitol to reduce any covalent $\beta$ - $\mathrm{Lg}$ aggregates that might have been formed during heating, and subsequent analysis in a buffer containing urea (according to Otte et al., 1997) did not improve the resolution between the variously lactosylated forms (results not shown).

At low $\mathrm{pH}, \beta$ - $\mathrm{Lg}$ is positively charged and migrates towards the cathode according to its net charge. The longer migration times of the lactosylated species of $\beta$ - $\mathrm{Lg}$ implies that these are either less positively charged or have a larger molecular size. Since binding of sugar to lysine induces a slight change of the $\mathrm{p} K_{\mathrm{a}}$ value of the amino group but does not remove the charge (Bunn et al., 1979; Nacka et al., 1998), the net positive charge of the lactosylated $\beta$-Lg probably is slightly lower than that of native $\beta-\mathrm{Lg}$ at $\mathrm{pH} 2.5$. Thus, the retarded migration time of the lactosylated forms of $\beta-\mathrm{Lg}$ as shown in Fig. 1 could be due to both a lower net charge and a higher mass and/or more extended conformation of the

Table 1. Capillary Electrophoretic Conditions Used for Analysis of Lactosylated $\beta$-Lactoglobulin

\begin{tabular}{|c|c|c|c|}
\hline Mode & Buffer & Additives & Voltage \\
\hline \multirow[t]{6}{*}{ CZE } & $0.15 \mathrm{M}$ phosphate, $\mathrm{pH} 2.5^{\mathrm{a}}$ & None & $13 \mathrm{kV}-58 \mu \mathrm{A}$ \\
\hline & $0.01 \mathrm{M}$ phosphate, $\mathrm{pH} 2.7^{\mathrm{a}}$ & $\begin{array}{l}4 \mathrm{M} \text { urea } \\
+0.02 \% \mathrm{HPMC}^{\mathrm{b}}\end{array}$ & $25 \mathrm{kV}-39 \mu \mathrm{A}$ \\
\hline & $0.10 \mathrm{M}$ borate, $\mathrm{pH} 9.2$ & None & $22 \mathrm{kV}-33 \mu \mathrm{A}$ \\
\hline & $0.10 \mathrm{M}$ borate, $\mathrm{pH} 9.2$ & $\mathrm{PEG}^{\mathrm{c}} 0.25 \%$ & $23 \mathrm{kV}-34 \mu \mathrm{A}$ \\
\hline & $0.10 \mathrm{M}$ borate, $\mathrm{pH} 9.2$ & $\mathrm{PVA}^{\mathrm{d}} 0.05 \%$ & \\
\hline & $0.10 \mathrm{M}$ borate, $\mathrm{pH} 9.2$ & 2-propanol, 1:9 & $25 \mathrm{kV}-28 \mu \mathrm{A}$ \\
\hline MECC & $25 \mathrm{~mm}$ SDS, $40 \mathrm{~mm}$ borate, $\mathrm{pH} 9.2$ & 2-propanol 5\% & $22 \mathrm{kV}-52 \mu \mathrm{A}$ \\
\hline
\end{tabular}

a Analysed using Waters Quanta 4000 capillary electrophoresis system.

${ }^{\mathrm{b}} \mathrm{HPMC}=$ hydroxypropyl methylcellulose.

c PEG = Polyethylene glycol.

${ }^{\mathrm{d}} \mathrm{PVA}=$ Polyvinyl alcohol. 


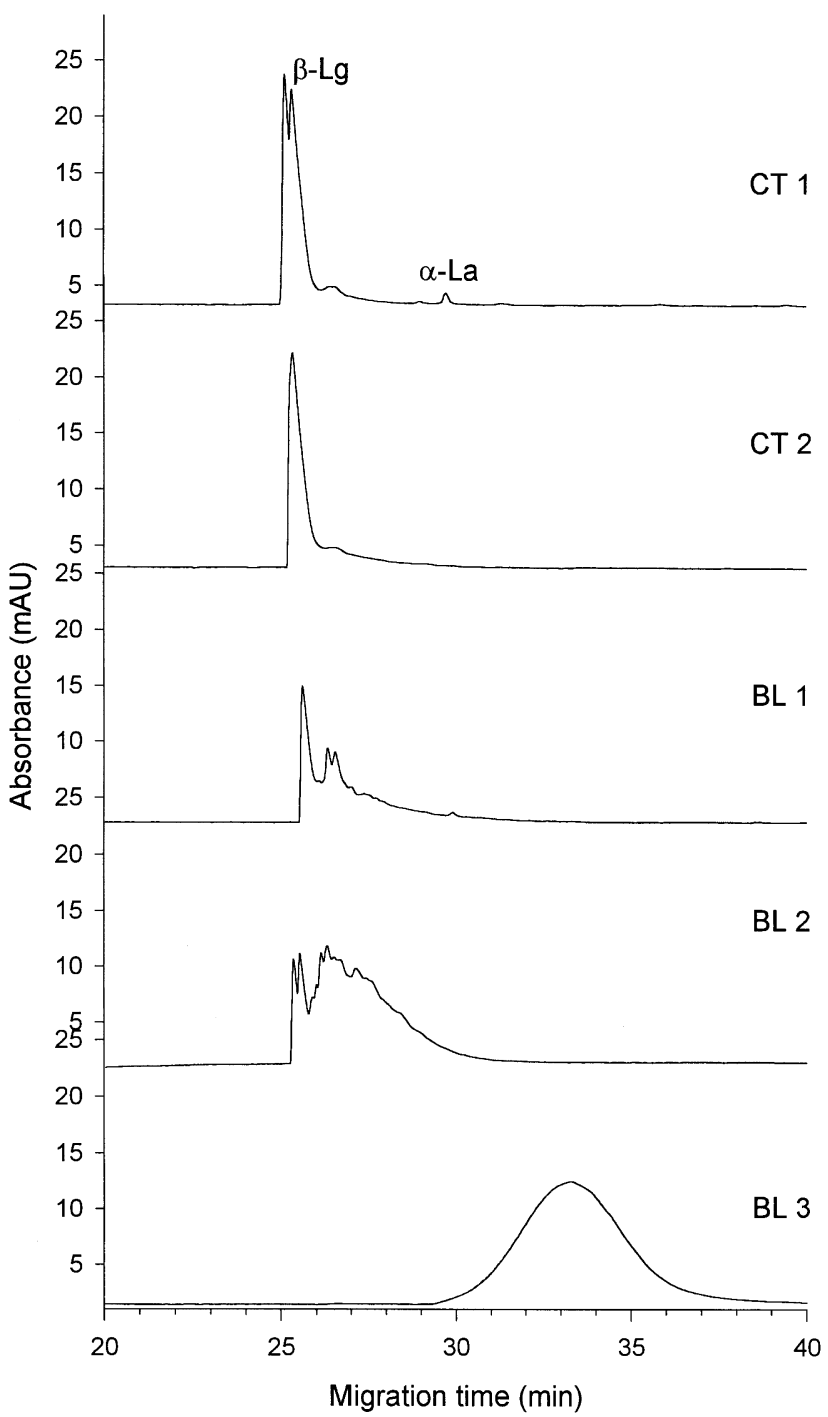

Fig. 1. Capillary electrophoresis at $\mathrm{pH} 2.5$ of native $\beta$-lactoglobulin (CT1 and CT2) and the same $\beta$-lactoglobulin lactosylated to various degrees (BL1-BL3). Analysis was performed on Waters Quanta 4000 system using a $0.15 \mathrm{M}$ phosphate buffer, $\mathrm{pH} 2.5$, other conditions as described in the methods section. $\beta$-Lg, $\beta$-lactoglobulin; $\alpha$-La, $\alpha$-lactalbumin.

protein. Addition of a mass of 324 as resulting from attachment of $1 \mathrm{~mol}$ of lactose per mole of $\beta$ - $\mathrm{Lg}$, however, would only change the molecular mass by $1-2 \%$, and is not per se expected to give a significant retardation in migration time. However, if the binding of lactose results in partial unfolding of the protein, the frictional force would be increased and increased migration time results. Furthermore, partial unfolding could lead to aggregation of $\beta$ - $\mathrm{Lg}$ molecules with formation of oligomers and high molecular weight polymers. Oligomers and polymers of $\beta$ - $\mathrm{Lg}$ are known to have a longer retention time in capillary electrophoresis than $\beta$ - $\operatorname{Lg}$ (unpublished results from our lab). SE-HPLC of the samples, however, showed that oligomers were not formed, although the retention time of the lactosylated samples gradually decreased from 12.5 to 12.0 min corresponding to an increase in molecular weight of approximately $5 \mathrm{kDa}$.

Alternatively, the hydrophilic glycosidic groups might adsorb to the protonated silanol groups of the inner capillary wall retarding the migration of the lactosylated $\beta$-Lg species.

\section{High $p H$}

At high $\mathrm{pH}$, both the proteins and the capillary wall are negatively charged and the net electrophoretic mobility towards the cathode is carried by the electro-osmotic flow. Since the A variant of $\beta$-Lg has one negative charge more than the B variant (Asp64/Gly64), it has a slower migration towards the cathode (Fig. 2).

Upon analysis of the control samples (CT1 and 2) using the borate buffer, the A variant of $\beta$ - $\mathrm{Lg}$ seemed to split into two components (Fig. 2A). This was also the case when a mixture of the pure $\mathrm{A}$ and $\mathrm{B}$ variants were analysed (Fig. 2B). The reason for this phenomenon is unclear. It is probable that the minor peak represents the dimer form of $\beta$-Lg. Aymard et al. (1996) have shown that $\beta$ - $\mathrm{Lg}$ exists as a mixture of monomer and dimer even at extreme $\mathrm{pH}$ values.

Figure 2A further shows that with increasing lactosylation, the peak representing native $\beta$ - $\mathrm{Lg}$ is decreased and a number of peaks with longer migration time appear. The heaviest lactosylated sample (BL3) had a migration time significantly longer than the native $\beta$ - Lg and the less lactosylated forms, showing that also under these conditions the lactosylated forms of $\beta$ - $\mathrm{Lg}$ had a longer migration time than the native proteins.

Separation of glycosylated forms from the nonglycosylated forms of $\beta$ - $\mathrm{Lg}$ might partly be due to use of borate buffer, which form complexes with vicinal hydroxyl groups. Borate was used by Oda and Landers (1996) to separate a range of glycoforms of bovine transferrin. Vicinal hydroxyl groups in the cis configuration are present in the galactose part of the Amadori compound (Morgan et al., 1997). Complexation with borate leads to additional negative charge and thus retarded migration times, which is in accordance with the results presented in Fig. 2. However, the longer migration time of the lactosylated species may also be due to their slightly higher net negative charge in comparison to the unmodified $\beta$ - $\mathrm{Lg}$, and perhaps also to some unfolding of the lactosylated $\beta$-Lg molecules, or adsorption to the capillary wall.

In order to improve the separation of the variously lactosylated forms of $\beta$ - $\mathrm{Lg}$, a range of buffer additives were tested. The organic modifier, 2-propanol, is believed to act by increasing the buffer viscosity, and thus lower the electro-osmotic flow. In accordance with this, longer migration times were observed when the $\beta$ - $\mathrm{Lg}$ samples were analysed in the presence of $10 \%$ 2-propanol and separation of the variously lactosylated $\beta$ - $\mathrm{Lg}$ species was slightly improved (Fig. 3A) when compared to the separation shown in Fig. 2.

Inclusion of polymers, polyethylene glycol (PEG) or polyvinyl alcohol (PVA), to reduce the electroosmotic flow (by reducing the zeta potential across the diffuse layer of counter ions near the capillary wall) and to reduce adsorption of proteins by shielding the silanol groups resulted in separations very similar to that obtained by addition of 2-propanol (Fig. 3).

It cannot be assessed from the present results, if separation of $\beta$ - $\mathrm{Lg}$ species differing in only one lactose unit can be achieved by one of the CZE methods presented, because of the structural heterogeneity of the lactosylated protein used (Morgan et al., 1997). This will be known if one single variant of $\beta$-Lg with a homogeneous binding of lactosyl units is used. 


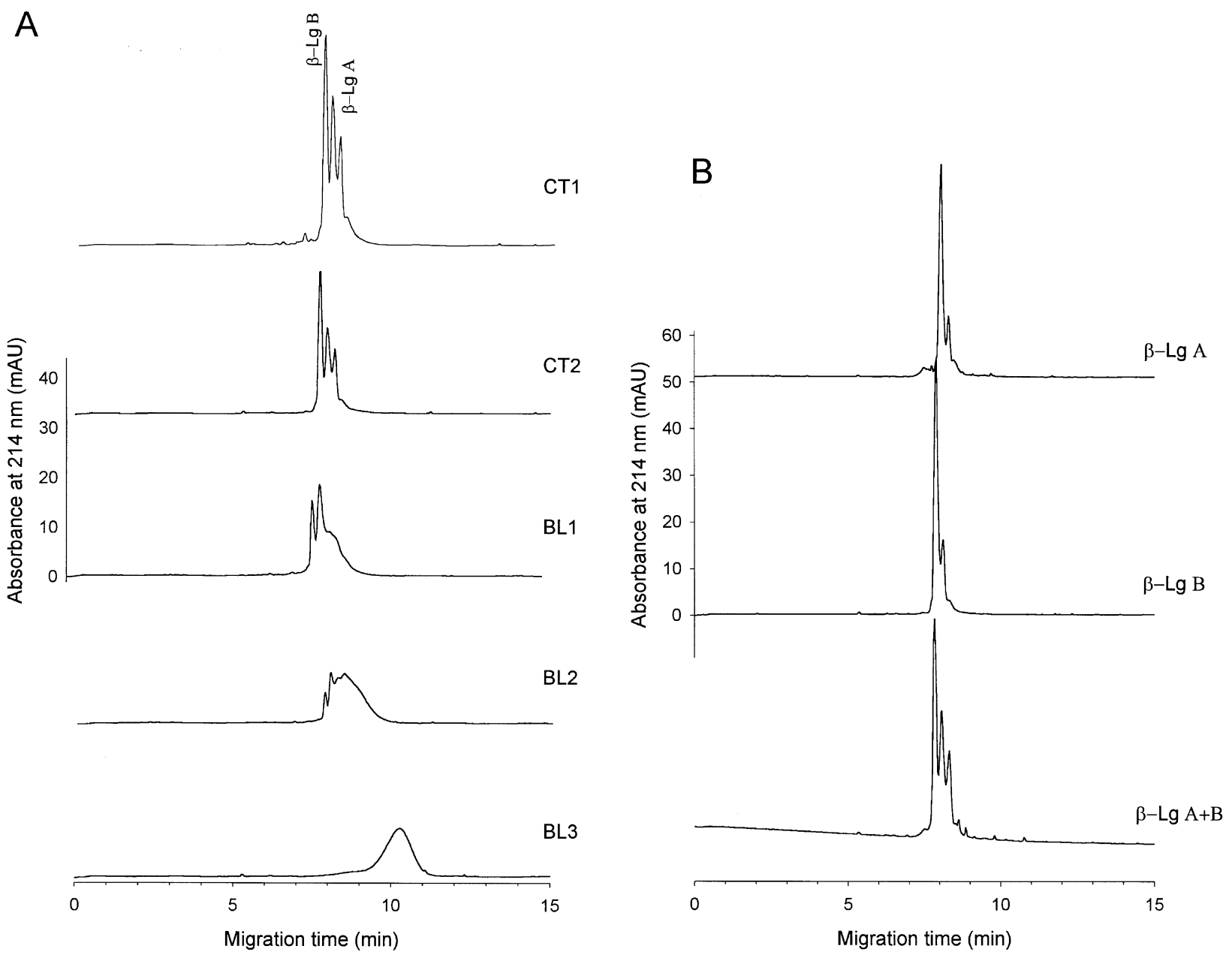

Fig. 2. Capillary electrophoresis at $\mathrm{pH} 9.2$ of $\beta$-lactoglobulin $\mathrm{AB}$ with various degrees of lactosylation (A) and purified $\beta$-lactoglobulin $\mathrm{A}$ and $\mathrm{B}$ individually and in a $1: 1$ mixture (B). Analysis was performed on HPCE with a $100 \mathrm{mM}$ borate buffer without additives.

A

CT1

BL1

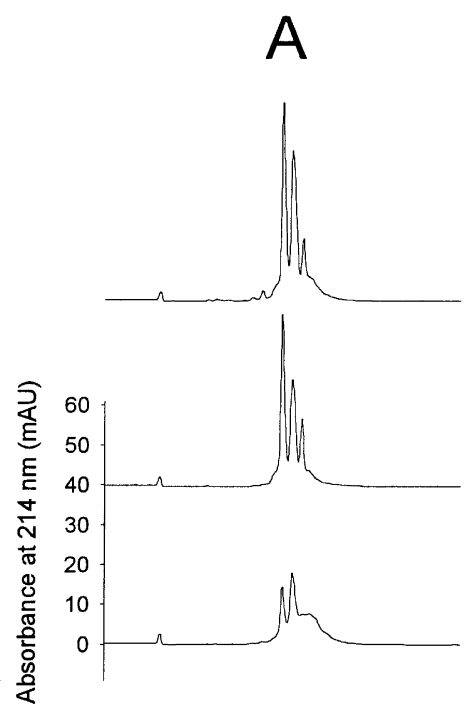

BL2

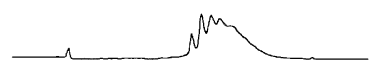

BL3

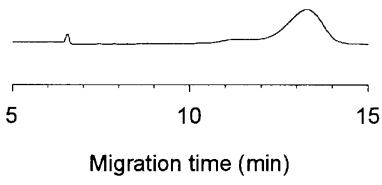

B
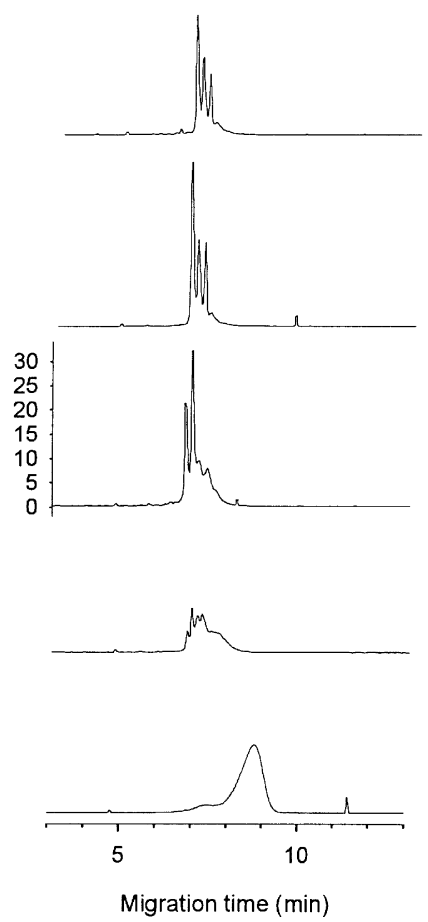

C
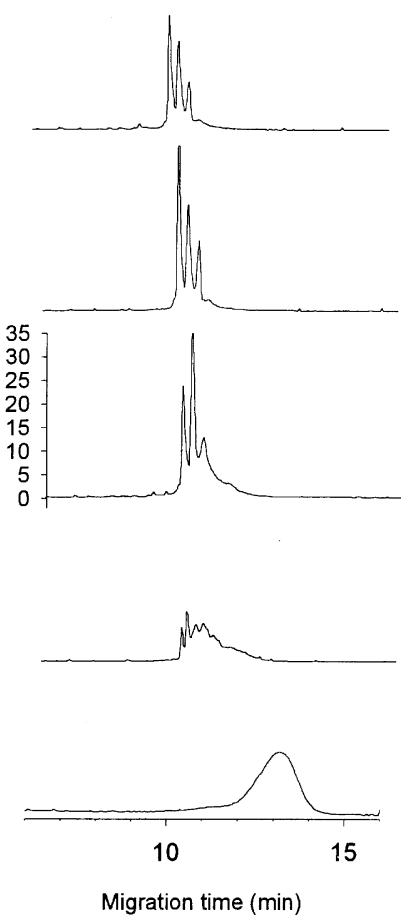

Fig. 3. Capillary electrophoresis at $\mathrm{pH} 9.2$ of native $\beta$-lactoglobulin and $\beta$-lactoglobulin lactosylated to various degrees (see Materials). Analysis was performed on HPCE with a $100 \mathrm{~mm}$ borate buffer diluted 9:1 with 2-propanol (A), or containing $0.25 \%$ (w/v) PEG (B) or $0.05 \%(\mathrm{w} / \mathrm{v})$ PVA (C). 

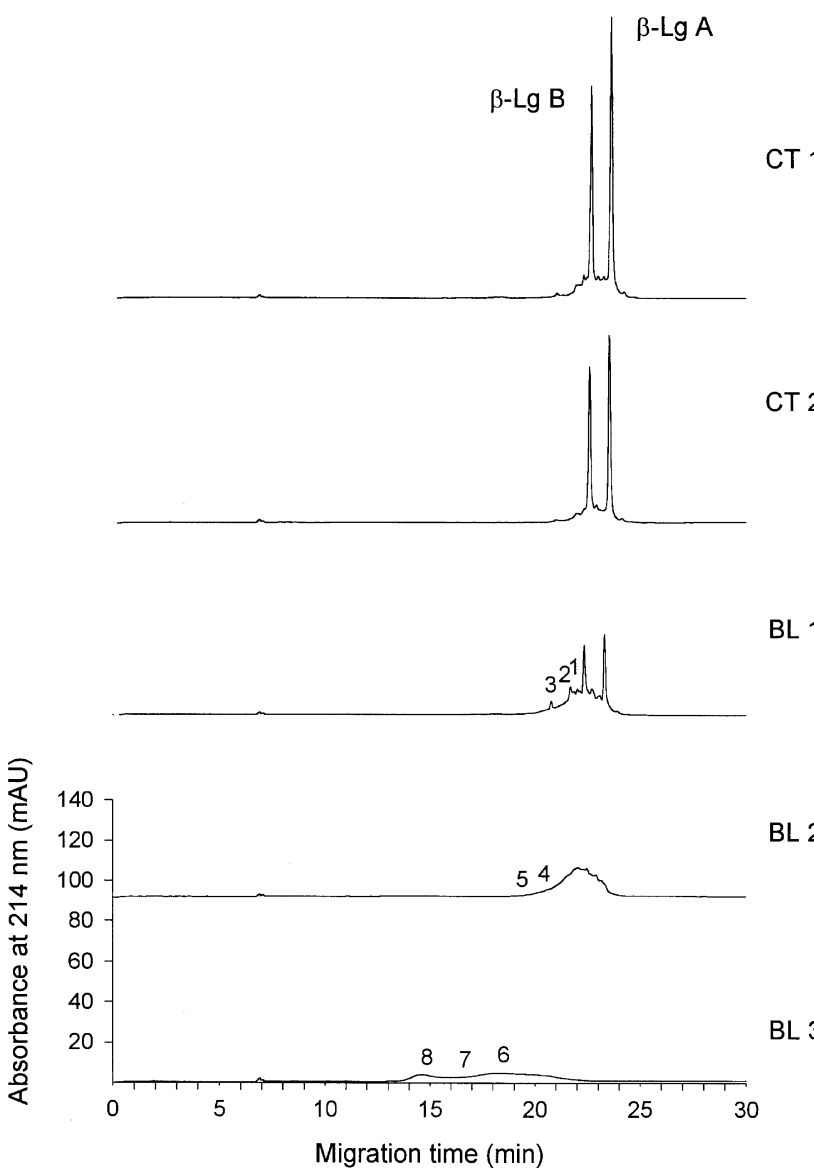

Fig. 4. Micellar electrokinetic chromatography of native $\beta$-lactoglobulin $\mathrm{AB}$ and $\beta$-lactoglobulin lactosylated to various degrees as described in the Materials section. Conditons as presented in Table 1 . Numbers above peaks refer to the expected number of lactose units.

\section{Micellar electrokinetic chromatography (MECC)}

Apparently, lactosylation led to decreased interaction with the SDS micelles, since the most lactosylated sample had a much shorter migration time than the native $\beta$-Lg when analysed by MECC (Fig. 4). Probably, the hydrophilic lactosyl groups impaired the interaction of $\beta-\mathrm{Lg}$ with the hydrophobic part of the SDS micelles, although less interaction with the SDS micelles could also partly result from the slightly higher net negative charge of the lactosylated $\beta-\mathrm{Lg}$ species. The MECC method using SDS micelles in a borate buffer at $\mathrm{pH} 9$, thus, also has potential for a qualitative separation of $\beta$ - $\mathrm{Lg}$ with varying numbers of lactose units.

Figure 4 further shows that the most lactosylated sample (BL3) appeared in MECC as a partly divided elongate region. Since the BL3 samples contained mainly $\beta$-Lg molecules with 6-8 lactosyl units attached, it can be guessed that this region corresponds to $\beta$ - $\mathrm{Lg}$ with mainly 8-6 lactosyl units attached and only few molecules with a lower number of lactosyl units.

\section{CONCLUSIONS}

The present results show that it is possible to separate native $\beta$ - $\mathrm{Lg}$ from lactosylated $\beta$ - $\mathrm{Lg}$ by capillary elec- trophoresis. Further, forms of $\beta$ - $\mathrm{Lg}$ with varying degree of lactosylation were partly separated. Separation can be achieved by simple capillary zone electrophoresis at either low or high $\mathrm{pH}$, in which case the lactosylated forms are delayed in comparison to the native $\beta$ - $\mathrm{Lg}$. The CZE methods at $\mathrm{pH} 2.5$ and at $\mathrm{pH} 9.2$ with 2-propanol as an additive (Figs 1 and $3 \mathrm{~A}$ ) seemed to give the best resolution between native and lactosylated $\beta$ - $\mathrm{Lg}$, and also between $\beta$-Lg species with varying number of lactose units. Separation of $\beta$ - $\mathrm{Lg}$ with varying number of lactose molecules attached can also be achieved by MECC using SDS, in which case the lactosylated forms have shorter migration times, due to less interaction with the SDS micelles.

CE, thus, can be used as a simple means to estimate the degree of lactosylation of $\beta$ - $\mathrm{Lg}$, and possibly other whey proteins, and thus help to relate the structure to the activity of the protein. If coupled to electrospray ionization mass spectrometry, detailed on-line characterization of the various species of lactosylated $\beta-\mathrm{Lg}$ would be possible.

\section{ACKNOWLEDGEMENTS}

K. R. Kristiansen is thanked for provision of pure $\beta$ - $\mathrm{Lg}$ samples. The technical assistance from Mila Zakora is highly appreciated.

\section{REFERENCES}

Arentoft, A. M., Frøkier, H., Michaelsen, S., Sørensen, H. and Sørensen, S. (1993) High-performance capillary electrophoresis for the determination of trypsin and chymotrypsin inhibitors and their association with trypsin, chymotrypsin and monoclonal antobodies. Journal of Chromatography A 652, 189-198.

Aymard, P., Durand, D. and Nicolai, T. (1996) The effect of temperature and ionic strength on the dimerisation of $\beta$-lactoglobulin. International Journal of Biological Macromolecules 19, 213-221.

Bunn, H. F., Shapiro, R., McManus, M., Garrick, L., McDonald, M. J., Gallop, P. M. and Gabbay, K. H. (1979) Structural heterogeneity of human haemoglobin A due to nonenzymatic glycosylation. Journal of Biological Chemistry 254, 3892-3898.

Burr, R., Moore, C. H. and Hill, J. P. (1996) Evidence of multiple glycosylation of bovine $\beta$-lactoglobulin by electrospray ionisation mass spectrometry. Milchwissenschaft 51, 488-492.

Færgemand, M., Otte, J. and Qvist, K. B. (1998) Cross-linking of whey proteins by enzymatic oxidation. Journal of Agricultural and Food Chemistry 46, 1326-1333.

Kats, M., Richberg, P. C. and Hughes, D. E. (1997) Conformational transformations of the fusion protein BR96 sFv-PE40 as monitored by micellar electrokinetic capillary chromatography and circular dichroism. Journal of Chromatography A 766, 205-213.

Kristiansen, K. R., Otte, J., Ipsen, R. and Qvist, K. B. (1998) Large-scale preparation of $\beta$-lactoglobulin A and B by ultrafiltration and ion-exchange chromatography. International Dairy Journal 8, 113-118.

Léonil, J., Mollé, D., Fauquant, J., Maubois, J.-L., Pearce, R. J. and Bouhallab, S. (1997) Characterization by ionization mass spectrometry of lactosyl $\beta$-lactoglobulin conjugates formed during heat treatment of milk and whey and identification of one lactose-binding site. Journal of Dairy Science 80, 2270-2281. 
Morgan, F., Léonil, J., Mollé, D. and Bouhallab, S. (1997) Nonenzymatic lactosylation of bovine $\beta$-lactoglobulin under mild heat treatment leads to structural heterogeneity of the glycoforms. Biochemical and Biophysical Research Communications 236, 413-417.

Morgan, F., Bouhallab, S., Mollé, D., Henry, G., Maubois, J.-L. and Léonil, J. (1998) Lactolation of $\beta$-lactoglobulin monitored by electrospray ionisation mass spectrometry. International Dairy Journal 8, 95-98.

Nacka, F., Chobert, J.-M., Burova, T., Léonil, J. and Haertlé, T. (1998) Induction of new physicochemical and functional properties by the glycosylation of whey proteins. Journal of Protein Chemistry 17, 494-503.

Oda, R. P. and Landers, J. P. (1996) Effect of cationic buffer additives on the capillary electrophoretic separation of serum transferrin from different species. Electrophoresis 17, 431-437.
Otte, J., Midtgaard, L. and Qvist, K. B. (1995) Analysis of caseinomacropeptide(s) by free solution capillary electrophoresis. Milchwissenschaft 50(2), 75-79.

Otte, J., Zakora, M., Kristiansen, K. R. and Qvist, K. B. (1997) Analysis of bovine caseins and primary hydrolysis products in cheese by capillary zone electrophoresis. Lait 77, 241-257.

Strege, M. A. and Lagu, A. L. (1993) Micellar electrokinetic capillary chromatography of proteins. Analytical Biochemistry 210, 402-410.

Taverna, M., Baillet, A., Biou, D., Schlüter, M., Werner, R. and Ferrier, D. (1992) Analysis of carbohydrate-mediated heterogeneity and characterization of $N$-linked oligosaccharides of glycoproteins by high performance capillary electrophoresis. Electrophoresis 13, 359-366.

Vincentelli, R. and Bihoreau, N. (1993) Characterization of each isoform of $\mathrm{F}\left(\mathrm{ab}^{\prime}\right) 2$ by capillary electrophoresis. Journal of Chromatography 641, 383-390. 